


\title{
PRODUCTIVITY, REPEATABILITY OF PRODUCTIVE AND REPRODUCTIVE TRAITS OF LOCAL PIGEON
}

\author{
S. Darwati ${ }^{1}$, H. Martojo ${ }^{1}$, C. Sumantri ${ }^{1}$, D.T.H. Sihombing ${ }^{1}$ and A. Mardiastuti ${ }^{2}$ \\ ${ }^{1}$ Faculty of Animal Science, Bogor Agricultural University, \\ Jl. Agatis, Darmaga Campus, Bogor - Indonesia \\ ${ }^{2}$ Faculty of Forestry, Bogor Agricultural University, \\ Jl. Ulin, Darmaga Campus, Bogor - Indonesia \\ Corresponding E-mail: darwatisri@ rocketmail.com
}

Received June 10, 2010; Accepted November 30, 2010

\begin{abstract}
The purpose of this study was to know productivity and repeatability of local pigeon. Data were collected from 124 birds that reared under intensive management. The results showed that artificial pair was $100 \%$ and polygamy was $16 \%$ ( $n=62$ pair of pigeon). The ration of local pigeon consisting of $50 \%$ corn $+50 \%$ of commercial feed for starter broiler chicken can be applied in field. The average of egg production was 1.8 eggs/pair/period, egg weight was $17.7 \mathrm{~g}$, fertility was $96.6 \%$, hatching rate was $77 \%$, embryo mortality rate was $23 \%$, interval period from laying to hatching and suckling was 51 days, 31.4 days with hatching, and 17.6 days without hatching and suckling. The day old pigeon weight ranged 10.9-16.2 g. Repeatability value of productive traits was high, in which egg weight was 0.64 and day old pigeon weight was 0.737 . Repeatability of reproductive traits was low, that was fertility and hatchability was 0.12 and 0.048 , respectively). The squab weight increased from week 0 to 4 , then decreased in the week 5 . The growth rate was highest at the week 1, then decreased from the week 2 to 5 with the negative growth rate occur at the $5^{\text {th }}$ week. The squab growth rate followed a quadratic pattern. It was concluded that slaughter squab selection could be done at $4^{\text {th }}$ week old.
\end{abstract}

Keywords:Productivity, Local pigeon, Repeatability

\section{INTRODUCTION}

Local pigeon bird or local pigeon or stone pigeon is one of the fauna germ plasma in Indonesia. The qualitative and quantitative traits of local pigeon still variety. The hobbyist reared pigeon as pet animal, as performing bird i.e. flat race and fly high that called with kentongan at East Java. Some of them used the pigeon as food like chicken, duck and quail. Stern and Dickinson (2010) stated the rock pigeon today comprise populations of artificially selected, domestic breeds; escape feral; and wild populations. Largely urban-living birds, feral pigeon maintain the strikling plumage variations of their domestic ancestors. All three types of pigeon-wild, feral and domestic-exhibit fascinating social behaviors including multi character mate choice, sexual computation, brood reduction, offspring sex ratio manipulation, dominance behaviors coloniality and biparental care of young. Fekete et al. (1999) stated that the purpose of pigeon breeding was basically threefold: the production of sports pigeons, ornamental pigeons, and utility (meattype) pigeons.

The pigeon meat is delicious, usually prepared at restaurant or café. The consumer comes from intermediate until high-classed status because the price of pigeon meat is expensive. Bhuyan et al. (1999) reported that mean of moisture, extract, and protein were 66.94, 11.90 and $19.69 \%$, respectively and total ash of pigeon meat was 235.24. Calcium and phosphorus were 69.16 and $235.24 \mathrm{mg} / 100 \mathrm{~g}$, respectively.

Commonly, the owner of pigeons fed their pigeon only corn or other grains such as rice grain. Anggorodi (1995) stated that pigeon is able to consume simple feeds consisting of grains and a little good grit; the pigeon also needed clean water. Furthermore Janssens et al. (2000) and Sales and Janssens (2003) reported that most commercial pigeon feed were based on mixtures grains. The use of component pellets in pigeon feeding was still marginal. The pigeon needs good nutrient in the intensive rearing. The ration is necessary to obtain their productivity as expected, 
but pigeon ration is not sold commercially at the poultry shop. A mixed of corn and broiler diet were given to pigeon during production phase to fulfill pigeon nutrient requirement.

Genetic improvement is important to increase productivity through increasing gene frequency of reproduction. Growth traits enclosed with suitable environment can achieve maximal performance (Duma et al., 1989). Growth data is needed to support potential study of the pigeon as meat producer. Supporting repeatability data can be used to improve the local pigeon. Bourdon (2000) stated that repeatability is a measure of strength (consistency, reliability) of relationship between repeated records (repeated phenotypic value) for a trait in a population and the strength of relationship between single performance records and producing abilities. Repeatability can be determined for any trait in which individual commonly have more than one performance record. Examples of repeated traits is milk yield in dairy animals, racing and show performance in horse, litter size in swine, and fleece weight in sheep. As a correlation, repeatability ranges -1 to +1 , though only rarely are repeatability negative. Traits with repeatability below 0.2 are considered lowly repeatable, traits with repeatability 0.2-0.4 are considered moderately repeatable, and traits with repeatability above 0.4 considered highly repeatable. Repeatability is not fixed. It varies from population to population and from environment to environment.

The aim of this research was to study local pigeon productivity and repeatability value of productive and reproductive traits. Furthermore, the study of productivity and repeatability is supposed to be used for developing the local pigeon as meat producer.

\section{MATERIALS AND METHODS}

\section{Materials}

Adult local pigeon used are as much as 124 birds. Every pair of pigeon kept in individual cage $\left(60 \times 50 \times 50 \mathrm{~cm}^{3}\right)$ with cage wall made from wire measures $1.2 \times 1.2 \mathrm{~cm}^{2}$ as much as 62 cages. Every individual cage was completed by feed bowl, water trough and nest. Feed and water is given $a d$ libitum.

The research was conducted in three stages. Firstly, mating and polygamy mating. Secondly, try four kinds of feed and choosing the good feed to productivity. Thirdly, observation on the productivity and parameter genetic (repeatability). Naturally, the pigeon was permanently paired (monogamy) that was one male paired to one female. The first research was to try polygamy pairing, one male to more than one female.

The mating has be done in three steps: (1) the cock pigeon was putted into individual cage then the hen pigeon putted into the same individual cage with the cock as the candidate cock pigeon pair. If the cock pigeon make a noise bekur, then the hen pigeon approve, and the cock will follow or chase hen wherever the hen go. Then both of them flirt such the cock regurgitate hen and they become a pair. (2) The cock and its pair candidate, female pigeon that will be matted with, are putted into different individual cage side by side and so both of them can see each other. If they show a good contact, they will be placed in the same cage. After that, if the cock bekur and the hen dances as keep nodding its head and the cock regurgitate then they are paired successfully. (3) The cock and the hen that will be paired were trapped in a dark room for a moment. They are taken out from the dark room where there are no other birds. If both of them mated, they will show behavior like in a natural mating. The total pigeon that successfully mated was calculated in percentage.

The second research was to select the ration that suitable for the pigeon on intensive management. Four kinds of ration were used: $100 \%$ corn (A), $50 \%$ corn $+50 \%$ commercial feed (B); $100 \%$ commercial feed (C); $30 \%$ corn $+50 \%$ commercial feed $+20 \%$ brown rice (D). The form of commercial feed was crumble. Nutrient composition of A feed consisted of $12 \%$ crude protein, $1.5 \%$ fiber, $6 \%$ fat; $\mathrm{B}$ feed consisted of $15.5 \%$ crude protein, $2.4 \%$ fiber, $6.5 \%$ fat; $\mathrm{C}$ feed consisted of $19 \%$ crude protein, $3.3 \%$ fiber, $7 \%$ fat; D feed consisted of $15 \%$ crude protein, $2.3 \%$ fiber, $6 \%$ fat. Feed selection based on hen egg production and squab growth. Egg weight was measured before the pigeon pair brood their eggs. Day old pigeon weight was measured at a moment before the squab was hatched. The squab weight was measured weekly. Sumadi (1991) replaced crop milk with beginner feed shaped milk and egg that can increase egg production per year. In general, replacing crop milk with egg is better than giving milk during two first weeks.

Based on the second research, B feed was selected to be used as the pigeon feed in the next research. Data of production and reproduction traits were collected in the third research. Data of 
productive trait were calculated to get repeatability value. Feed requirement for each pair of pigeons in brooding phase, suckling phase and producing phase was registered in the third research. Feed consumption data every phase is averaged. So, the feed consumption registration includes feed consumption in brooding phase (18 days), suckling phase (35 days), producing phase (from the squab weaned until the hen laid eggs).

Pigeon egg weight from each pair was measured. A pigeon pair laid two eggs per laying period, and then they brood their eggs until 18 days. Fertility data was taken from egg fertile divided by total egg clutched of pigeon pair. Hatchability data was taken from day old pigeon divided by total fertile egg. Squab feed conversion was calculated from comparison between feed consumption with squab body weight gain. Feed conversion squab was calculated per week. Feed consumption of squab was maternal feed consumption minus maternal maintenance requirement $(55 \mathrm{~g})$. Data of production and reproductive traits were egg weight, day old pigeon, weaning weight, fertility, hatchability and mortality as much as three periods, which used to measure repeatability value.

\section{Data analysis}

The success of mating pigeon as polygamy pair is measured in percentage and is presented descriptively. The randomized completed pattern was used in feeding trial for choosing good kinds of feed (Mattjik and Sumertajaya, 2002). Data that was measured as preceding pattern includes egg weight, day old pigeon and squab growth. The growth rate is estimated according to following Bokhari (2002). The nested randomized completed pattern is used to evaluate repeatability data (Becker, 1975).

\section{RESULT AND DISCUSSION}

If the cock pigeon was putted into individual cage that consisted of hen pigeon bekur and the hen dance, then the cock followed the hen. The cock regurgitated the hen so those birds become the pair for mating. In this research $100 \%$ pair of pigeon was resulted by artificial pair mating. In artificial pair mating, there were 10 cock pigeons mated to two hen pigeon (polygamy: 16\%), but this polygamy pair of productivity was low, that was only one squab alive up to adult although the eggs were fertile and hatch but squabs were died just a moment after hatched. Therefore, that in following stage polygamy pair was not used.

Feed is used to meet requirement for maintenance, production and reproduction. The pigeon need feed in production phase for egg production. In suckling moment the cock and hen of squab require feed for growth of squab until the squab can eat by itself. Feed was needed by parental for basal requirement. The hen pigeon must be prepared to laying, but the feed contained high nutrient more expensive than the feed contained low nutrient.

The pigeon preferable grain. Hobbyist and farmer usually give corn as pigeon feed. Four feed kinds were tried to the birds. Production data was collected to evaluate performance of the pigeon. Egg weight and squab growth are presented in Table 1.

The feed consist of mixture 50\% corn $+50 \%$

Table 1. Egg Weight and Squab Growth by Different Feed

\begin{tabular}{|c|c|c|c|c|}
\hline \multirow{2}{*}{ Variable } & \multicolumn{4}{|c|}{ Feed } \\
\hline & A & B & $\mathrm{C}$ & $\mathrm{D}$ \\
\hline Egg w eight (g) & $16.56 \pm 1.02^{\mathrm{a}}$ & $18.53 \pm 1.20^{\mathrm{b}}$ & $17.38 \pm 0.97^{\mathrm{a}}$ & $18.27 \pm 1.37^{b}$ \\
\hline Day old pigeon (d) & $13.62 \pm 1.22^{\mathrm{a}}$ & $14.58 \pm 1.06^{\mathrm{b}}$ & $13.60 \pm 1.00^{\mathrm{a}}$ & $14.61 \pm 1.01^{\mathrm{b}}$ \\
\hline Body Weight on $1^{\text {st }}$ week $(\mathrm{g})$ & $110.86 \pm 46.10$ & $119.36 \pm 19.71$ & $118.97 \pm 22.23$ & $97.08 \pm 21.76$ \\
\hline Body Weight on $2^{\text {nd }}$ week (g) & $150.18 \pm 38.23^{\mathrm{a}}$ & $240.08 \pm 38.29^{b}$ & $202.96 \pm 45.26^{c}$ & $199.06 \pm 26.72^{\circ}$ \\
\hline Body Weight on $3^{\text {th }}$ week $(\mathrm{g})$ & $209.05 \pm 52.81^{\mathrm{a}}$ & $279.56 \pm 76.98^{b}$ & $262.26 \pm 42.12^{\mathrm{b}}$ & $253.44 \pm 38.93^{b}$ \\
\hline Body Weight on $4^{\text {th }}$ week $(\mathrm{g})$ & $233.95 \pm 5.85^{\mathrm{a}}$ & $300.00 \pm 37.80^{c}$ & $287.88 \pm 28.67^{\mathrm{b}}$ & $295.00 \pm 12.00^{\circ}$ \\
\hline Weaning weight (g) & $226.15 \pm 53.98^{\mathrm{a}}$ & $288.00 \pm 35.10^{\mathrm{b}}$ & $288.83 \pm 21.68^{\mathrm{b}}$ & $320.00 \pm 26.93^{\circ}$ \\
\hline Mortality (\%) & 37.5 & 27.27 & 0 & 43.75 \\
\hline
\end{tabular}

A: $100 \%$ corn

B: $50 \%$ corn $+50 \%$ commercial feed ;

C: $100 \%$ commercial feed;

D: $30 \%$ corn $+50 \%$ commercial feed $+20 \%$ brown rice 
of commercial feed can be applied because the squabs growth were good and showed lower mortality. This feed type was called B types of feed $(50 \%$ corn $+50 \%$ commercial feed), when it was sold at market, the price was cheaper compared to the price of A, C and D.

In brooding phase, little activity of cock and hen pigeons were observed. This research showed that the pigeon fulfilling requirement of maintenance only during brooding (55-58 g/day/pair), a pair of pigeon needed feed 83-99 $\mathrm{g} /$ day for suckled two squabs. A pair of pigeon needed more feed to produce egg in comparison to basal requirement. A pair of pigeon needed 60$80 \mathrm{~g} /$ day/pair to produce an egg consisted of corn and commercial ration. In this phase, the cock and hen pigeons consumed the feed for preparation lays that was begun from drive ("giring" for cock and hen) and reproduction especially to the hen for egg cell maturation. In regurgitation phase, feed consumption of cock and hen pigeon increased up to the $3^{\text {th }}$ weeks suckling, but consumption of ration decreased, average of feed consumption increased because corn consumption increased. Commercial ration proportion towards was highest to compared corn in the week 1 , squab needed soft feed and contain high nutrient (feed contained protein 15\%). This matter is caused squab also received crop milk that was produced by gland in cock and hen crop. The squab was suckled by cock and hen pigeon also, while hard feed likes corn was suckled to squab by cock and hen from 6 days age in this research.

The productivity traits included reproductive and productive trait. The productive traits are presented in Table 2. The cock and hen pigeon brood self the egg according to by turns between cock and hen pigeon with the hen incubation time allocation was longer compared to the cock. The hen pigeon lied egg again 17-18 days after brooding. The cock clutch egg in morning until evening (10 a.m.-15 p.m) furthermore the hen replaced the cock to brood egg until the next morning moment the cock continue as a replacement to broods. In this research it was found 12 pigeon pairs $(17.6 \%)$ did not want to brood. The pigeon pair that wanted to brood the egg as much as $82.4 \%$. Variation of brood trait is influenced by genetic factor and there is no selection for character of good brood (maternal trait). Also, it was found that pigeon didn't brood because they frown on the nest that provided. However, in this research there were three hen pigeons that could to clutch self the egg up to the child hatched even can suckled squab self.

Normally the pigeon lays two eggs per laying period. In this research, the egg production per pair of pigeon ranged 1-3 eggs, three hens laid 1 egg and 1 hen laid 3 eggs per egg laying period. Levi (1945) proposed that the pigeon lies as much as 1-3 eggs per period, averagely as much as two eggs per period.

The egg weight ranged 10.7-23.2 g with mean $17.7 \pm 1.6 \mathrm{~g}$ and coefficient of variation $9 \%$. Ensminger (1992) stated that egg weight is influenced by breed, body weight and sex man's estate. Egg weight is influenced by the egg total that produced per year, sequence egg in clutch, level protein in ration, feed and drinking water, ambient temperature, stable type and disease also. The egg weight showed inclination, egg weight was in period $1<2=3<4=5=6\left(\mathrm{P}<0.05, \mathrm{n}_{1}=372\right.$, $\left.\mathrm{n}_{2}=159, \mathrm{n}_{3}=109, \mathrm{n}_{4}=66, \mathrm{n}_{5}=36, \mathrm{n}_{6}=16\right)$. Egg weights per period in this research were $17.16 \mathrm{~g}$ : $17.86 \mathrm{~g} ; 17.98 \mathrm{~g} ; 18.36 \mathrm{~g} ; 18.32 \mathrm{~g}$ and $18.58 \mathrm{~g}$ each in a series. The first egg weight was vary (coefficient of variation was $11.08 \%$ ). In the next period, egg weight variation decreased and more uniform compared to the first period. The first egg weight and second period the egg weight were not significant $\left(\mathrm{P}<0.05\right.$, t test, $\mathrm{n}_{1}=211$ and $\left.\mathrm{n}_{2}=162\right)$.

The oval pigeon egg form with egg index mean was $75.7 \pm 1.6 \%$ and coefficient of variation was $7.5 \%$. In this research the pigeon egg form approaches uniform. The color of eggshell was uniform that was white with thick of eggshell was $0.015 \mathrm{~mm}$.

The first age of laying egg on pigeon was $221 \pm 31$ day ages $(n=15)$ that ranged 125-366 days. Khargharia et al. (2003) reported that average for age at first egg of pigeon in Assam was $166.64 \pm 0.32$ days under traditional system management. The variation of laying first age was $32.4 \%$ in this research. Thereby ripe mother selection early or lay eggs fast first can make shorter generation interval.

Fertility and hatchability of pigeon in this study were $92.4 \%$ and $77 \%$, respectively. Fertility of pigeon was not different to quail. Petek et al. (2004) reported fertility of quail egg ranged $91.66-95.41 \%$. But hatchability was lower compared to Khargharia et al. (2003) that reported the hatchability to ranged from $78.64-82.62 \%$ in pigeon were reared under traditional system. Burden during incubation the breakdown of embryo death as big as $23 \%$ from egg fertile. Hatchability was influenced by many factors that 
Table 2. Performance of Productive Traits of Local Pigeon

\begin{tabular}{lccc}
\hline \multicolumn{1}{c}{ Variables } & Mean \pm SD & Range & Coefficient of Variance (\%) \\
\hline Maternal ability (\%) & 82.4 & - & - \\
Egg weight (g) & $17.7 \pm 1.6$ & $12.0-30.0$ & 9 \\
Egg production (egg) & $1.8 \pm 0.6$ & $1.0-3.0$ & 33 \\
Shape index (\%) & $75.7 \pm 5.6$ & - & 7.5 \\
Fertility (\%) & 92.5 & - & - \\
Hatchability (\%) & 77.0 & - & - \\
Day old pigeon (g) & $14.0 \pm 1.2$ & $10.9-16.2$ & 8 \\
Embryo mortality rate (\%) & 23 & - & - \\
Laying interval period (days): & & & - \\
$\quad$ Hatching and suckling & 51.0 & - & - \\
$\quad$ Hatching only & 34.1 & - & - \\
Without hatching & 17.6 & - & \\
\hline
\end{tabular}

Table 3. Body Weight of Squab

\begin{tabular}{crcc}
\hline Week & Mean \pm SD $(\mathrm{g})$ & \multicolumn{1}{c}{ Range $(\mathrm{g})$} & Coefficient of Variance $(\%)$ \\
\hline 0 (hatched) & $14.02 \pm 1.20$ & $10.9-16.2$ & 8.56 \\
I & $112.22 \pm 27.98$ & $60.0-80.0$ & 24.93 \\
II & $202.77 \pm 47.51$ & $93.0-306.0$ & 23.43 \\
III & $256.16 \pm 8.24$ & $192.0-355.0$ & 22.74 \\
IV & $290.40 \pm 27.98$ & $170.0-340.0$ & 9.63 \\
V & $282.17 \pm 44.43$ & $135.5-340.0$ & 15.74 \\
\hline
\end{tabular}

was: temperature, humidity in egg incubation time hatches. Besides mother body, ability to clutch egg hatches is various. This matter caused egg total unity fertile that hatch in pigeon bird mothers in these research that was revolves 0- 2 eggs (hatchability of per pigeon couple was $0-100 \%$ ). Deeming and Wadland (2001); Deeming and Wadland (2002) stated mating ratio had not significant effect on embryonic mortality.

The hatch weight of squab ranged 10.9-16.2 g. The egg weight loss during incubation was $6 \%$ of egg weight. This matter showed that embryo required nutrition during incubation that got from egg and use for squab to development up the organ body to hatch.

Pause is interval laying time in one period with the next laying period. The average of pause without hatching was 17.6 days, pause with hatching was 34.1 days. The hen clutches egg during 18 days. Khargharia et al. (2003) reported that average for the clutch interval (the lying cycle) in pigeon was $47.44 \pm 0.11$ days.

Growth of squab growth was from hatch $(0$ day/day old pigeon) up to the mother weans squab in 35 age days (Table 3 ). The squab grows fast in week 1 to 3 (age 0-21 days, Table 4), in contrary, the growth rate decreased and negative in week 5 .

The squab growth had equation $\mathrm{Y}=11.2+$ $121 \mathrm{t}-13.3 \mathrm{t}^{2}$, where $\mathrm{Y}=$ body weight and $\mathrm{t}=$ time (age). Growth rate was quick until 14 days. The inflection point was in 21 age days. The growth rate began to go down at 21 age days. In squab, selection was best done at 21-28 age days, thereby squab will not belong criteria that be defended, so 
Table 4. Growth Rate and Feed Conversion of Squab

\begin{tabular}{ccc}
\hline Week & Growth Rate $(\%)$ & Feed Conversion \\
\hline 0- I & 155.58 & 2.95 \\
I - II & 62.57 & 3.42 \\
II - III & 23.27 & 6.3 \\
III - IV & 16.92 & 10.16 \\
IV - V & -2.87 & \\
\hline
\end{tabular}

Table 4.Repeatability Value of Productive dan Reproductive Traits

\begin{tabular}{lcc}
\hline \multicolumn{1}{c}{ Variables } & $\mathrm{R}$ & Standard Error \\
\hline Egg weight & 0.63 & 0.08 \\
Day old pigeon & 0.74 & 0.16 \\
Weaning weight (5 week) & 0.29 & 0.08 \\
Fertility & 0.12 & 0.11 \\
Hatchability & 0.05 & 0.09 \\
Mortality & 0.1 & 0.13 \\
\hline
\end{tabular}

it can be culled (slaughtered) at 21-28 age days. This was supported by statement of Hoffman and Fisher (2001) that wholesalers and retailers have had problems with meat quality specially since the meat derived from the older birds appear darker and is apparently tougher upon consumption after cooking.

Selection of body weight for broiler could be done in week 4. At that moment, the growth rate was low and body weight was highest, because body weight decrease in week 5 and lower from body weight in week 4 .

Feed conversion of squab was high in this research. This was because of high growth rate occurs during the first three weeks. It then decreased at the fourth and fifth weeks due to reductions in growth rate of squab (Table 4). This indicated that feed efficiency decreased with the increased in age so the local pigeon was not efficient to meat producer because Antawijaya (1988) reported that feed conversion of Homer King squab was 3.68 .

The value of repeatability on reproduction and production traits are presented in Table 4. Egg weight and day old pigeon weigh had high repeatability, which was 0.634 and 0.737 , respectively. The value of repeatability can be used to predict heritability $\left(h^{2}\right)$ thereby $h^{2}$ egg weight and day old pigeon had high because the repeatability of that traits were high can be used to predict parameter value genetic other that was heritability $\left(\mathrm{h}^{2}\right)$ and mean heritability of egg weight and day old pigeon weight were high also. As according to Noor (2008) and Etches (1996) that value of egg weight heritability follows second author were 0.6 and 0.4-0.85 respectively. Egg weight has high heritability. Mean individual selection with chooses female elder and male that has big egg can increase egg production. Okamoto and Ootuka (1998) stated that the repeatability of total egg weight quail in the large line was a little smaller than small line were 0.585 and 0.694 after long term selection for large or small 6 week body weight through 75 generation. The repeatability value of squab body weight in age 5 week was high, but repeatability value of reproduction character belongs to low. Repeatability value has use to guess maximum value heritability with value subdividing heritability low $(0-0.2),(>0.2-$ $0.4)$ and high (>0.4) (Martojo, 1992; Bourdon, 2000)

All the reproductive traits analyzed showed low value (hatchability was 0.048 and fertility was 0.124). Van Schalkwyk et al. (1996) reported that ostrich reproduction traits were moderately. All the reproduction traits analyzed were moderately repeatable, ranging from $0.38 \pm 0.07$ (hatchability percentage) to $0.51 \pm 0.06$ (percentage of embryonic deaths).

\section{CONCLUSION}

The feed consist of $50 \%$ corn $+50 \%$ commercial feed for broiler starter can be application in local pigeon. The squab weight increased from week 0 to 4 , then decreased in the week 5 . Body weight of squab was $288 \mathrm{~g}$ at four week ages. Squab growth follows the quadratic equation. The value of repeatability of productive traits were high and reproduction traits were low.

\section{REFERENCES}

Anggorodi, R. 1995. Nutrisi Ternak Unggas. PT Gramedia. Jakarta.

Antawijaya, T. 1988. Pengaruh pengelolaan loloh paksa (force feeding) terhadap performans piyik dan induk merpati Homer King. Tesis. 
Fakultas Pascasarjana, Institut Pertanian Bogor, Bogor.

Bhuyan, P., D.R. Nath and M. Hazarika. 1999. Influences of age and sex on nutritive value (Proximate composition) of squab and pigeon meat. Indian Vet.,J. June. 76: 530-532.

Bourdon, R.H. 2000. Understanding Animal Breeding. $2^{\text {nd }}$ Edition. Prentice Hall, Inc. United States of America.

Bokhari, S. 2002. Squabing Pigeons Breeder'Handbook. Bokhari Squab Farm. California.

Deeming, D. C. and D. Wadland. 2001. Observations on the patterns of embryonic mortality over the laying season of pheasants. Br.Poult.Sci. 42: 569-573.

Deeming, D. C. and D. Wadland. 2002. Influence of age and sex in commercial pheasants fowls on bird health and production, fertility, and hatchability of eggs. Br. Poult. Sci. 43:16-23.

Duma, Y, Sumadi and W. Hardjosubroto. 1998. The repeatability estimation of growth traits and cow's productivity of beef cattle at Bila River Ranch. Buletin Peternakan. 22(1):2-7

Ensminger, M.E. 1992. Poultry Production (Animal Agriculture Series). $3^{\text {rd }}$ Edition. Interstate Publishers. Denville. Illinis.

Etches, R. J. 1996. Reproduction in Poultry. CAB International. Canada.

Fekete, S., I. Meleg, I. Hullar and L. Zoldag. 1999. Studies on the energy content of pigeon feeds II. Determination of the incorporated energy. Poult. Sci. 78:1763-1767.

Hoffman, L.C. and P. Fisher. 2001. Comparison of meat quality characteristics young and old ostriches. Meat Sci. 59:335-33

Janssens, G. P. J., M. Hesta, V. Debaal and R.O.M. De Wilde. 2000. The effect of feed enzymes on nutrient and energy retention in young racing pigeon. Ann. Zootech. 49:10511556.

Khargharia, G., R.N. Goswin and D. Das. 2003. Performance of domestic pigeon of Assam in respect of some traits of reproduction. Indian
Vet.J. February.80:163-165.

Levi, W.M. 1945. The Pigeon. The R.I. Bryan Company. Colombia.

Martojo, H. 1992. Peningkatan Mutu Genetik Ternak. Departemen Pendidikan dan Kebudayaan. Direktorat Jenderal pendidikan Tinggi. Pusat Antar Bioteknologi. Institut Pertanian Bogor.

Mattjik, A. A. dan M. Sumertajaya. 2002. Perancangan Percobaan dengan Aplikasi SAS dan Minitab. Jilid I. IPB Press, Bogor

Noor, R.R. 2008. Genetika Ternak. PT Penerbit Swadaya. Jakarta.

Okamoto, S. and A. Ootuka. 1998. Repeatability of body weight, egg weight, shape index and egg composition weight in Japanese quail lines selected for large and small. Proceedings $6^{\text {th }}$ Asian Pasific Poultry Congress. Nagoya, Japan. June 4-7. P. 258259.

Petek, M., Y. Ozen and E. Karakas. 2004. Effect of ressesive White plumage colour incubation on hatchability and growth of quail hatched from breeders of different ages. Br.Poult.Sci. November. 6:769-774.

Sales, J. And G.P.J. Janssens. 2003. Nutrition of the domestic pigeon (Columba livia domestica). World's Poult. Sci. J. 59:221232.

Stern, C.A. and J.L. Dickinson. 2010. Encylopedia of Animal Behaviour. http://www.sciencedirect.com/science. Doi: 10.1016/B978-0-08-045337-0-8-00366-1.

Sumadi, I.K. 1991. Pengaruh penggantian susu tembolok dengan susu atau telur sebagai pakan awal terhadap performans piyik. Tesis. Fakultas Pascasarjana. Institut Pertanian Bogor. Bogor.

Van Schalkwyk, S. J., S. W.P . Cloete and J. A. de Kock. 1996. Repeatability and phenotypic correlations for body weight and reproduction in commercial ostrich breeding pairs. Br.Poult.Sci. 7:953-962 